Document downloaded from:

http://hdl.handle.net/10251/140819

This paper must be cited as:

Jimenez-Falcao, S.; De Luis-Fernández, B.; García-Fernández, A.; Llopis-Lorente, A.; DiezSánchez, P.; Sánchez, A.; Sancenón Galarza, F.... (25-0). Glucose-Responsive EnzymeControlled Mesoporous Nanomachine with a Layer-by-Layer Supramolecular Architecture. ACS Applied Bio Materials. 2(8):3321-3328. https://doi.org/10.1021/acsabm.9b00338

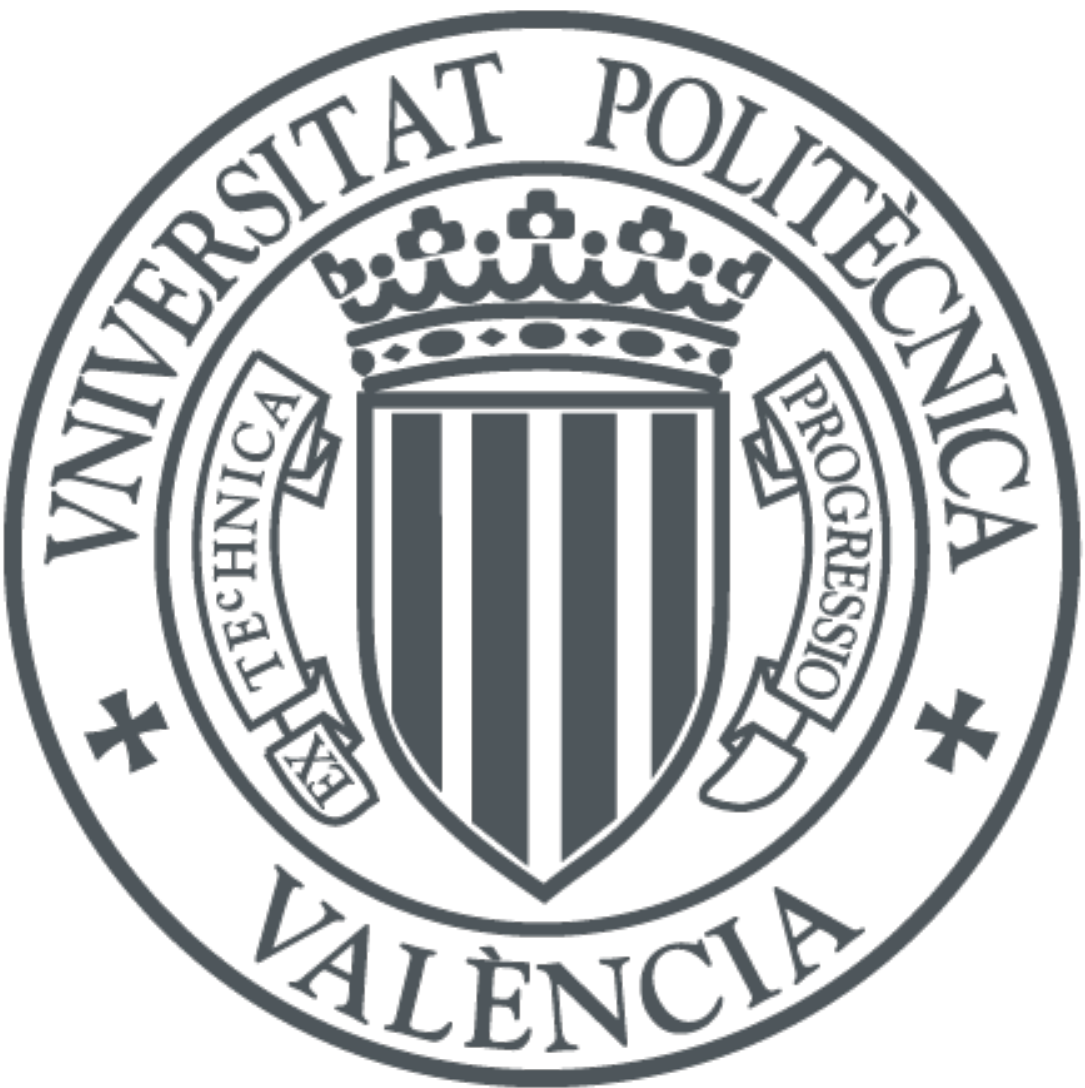

The final publication is available at

https://doi.org/10.1021/acsabm.9b00338

Copyright

Additional Information

American Chemical Society 


\title{
Glucose-Responsive Enzyme-Controlled Mesoporous Nanomachine with a Layer-by-Layer Supramolecular Architecture
}

Sandra Jimenez-Falcao, ${ }^{\dagger}$ Beatriz de Luis, ${ }^{\ddagger, \S, \|}$ Alba García-Fernádez, ${ }^{\ddagger, \S, \|}$ Antoni Llopis-Lorente, ${ }^{\ddagger, \S, \|}$ Paula Diez, ${ }^{\dagger}$ Alfredo Sańchez, ${ }^{\dagger}$ Félix Sancenón, ${ }^{\ddagger, \S, \|}$ Paloma Martínez-Ruiz, ${ }^{*}{ }^{\dagger}$ Ramón MartínezMáñez, ${ }^{*} \neq, \S, \|$ and Reynaldo Villalonga*,+

\begin{abstract}
${ }^{\dagger}$ Nanosensor \& Nanomachines Group, Department of Analytical Chemistry, Faculty of Chemistry, Complutense University of Madrid, Madrid 28040, Spain.

${ }^{\ddagger}$ Instituto Interuniversitario de Investigación de Reconocimiento Molecular y Desarrollo Tecnológico (IDM), Universitat Politècnica de València, Universitat de València, Camino de Vera s/n, Valencia 46022, Spain.
\end{abstract}

§Unidad Mixta UPV-CIPF de Investigación en Mecanismos de Enfermedades y Nanomedicina, Centro de Investigación Príncipe Felipe, Universitat Politècnica de València, Valencia 46022, Spain.

"CIBER de Bioingeniería Biomateriales y Nanomedicina (CIBER-BBN), Madrid 28029, Spain.

ABSTRACT: Here we describe the construction of an integrated and $\mathrm{pH}$-sensitive nanomachine with layer-by-layer supramolecular design and enzymatic control for on- command delivery. The nanodevice comprises a first layer of $\beta$-cyclodextrin-coated gold nanoparticles as capping element of benzimidazole functionalized mesoporous silica nanoparticles, and a second control layer based on an adatamantane-modified glucose oxidase derivative. The nanomachine was selectively fuelled by glucose and successfully employed for the autonomous release of doxorubicin in HeLa cancer cells

KEYWORDS: cyclodextrin, enzymes, mesoporous silica, delivery, gold nanoparticles.

Nowadays, the development of smart nanomachines able to perform sensing and actuating tasks in an autonomous and programmed way is a major scientific challenge because of their potential applications. ${ }^{1-3}$ Among other uses, these novel nanomachines could be employed to design more effective drug delivery systems, sensitive sensors, and nanostructured devices for pathogen control and environmental protection. ${ }^{4-7}$ In the field of drug delivery, mesoporous silica nanoparticles (MSN) have been largely employed as nanosized scaffold. ${ }^{8-10}$ This fact has been supported by their high loading capacity, low toxicity, high specific volume, and easy preparation with controlled pore and nanoparticle morphology and dimensions. ${ }^{11}$ Moreover, MSN can be rationally modified at their surface with stimulus-responsible molecular, biomolecular, or supramolecular ensembles, producing integrated nanocarriers able to release their cargo in response to external physical, chemical, or biochemical stimuli. ${ }^{12-15}$ However, despite the description of a large number of MSN mechanized with original gatelike ensembles for controlled delivery, ${ }^{8-15}$ the design of integrated autonomous nanodevices able to selectively deliver their cargo in the presence of simple molecular stimuli has barely been explored.

In previous works, we proposed the use of immobilized enzymes as biochemical units to control MSN-based nano- machines. ${ }^{6,16-21}$ These biocatalysts can act as sensing element able to detect 
the presence of target compounds in the environment which are recognized as enzyme substrates (INPUT signal). Enzymes catalyze their conversion to specific molecules than act as local "chemical messengers" able to operate the stimulus-responsible ensembles in the functionalized MSN nanocarrier allowing cargo release (OUTPUT signal). This hypothesis was successfully demonstrated by using enzymes or combination of enzymes acting as Boolean logic gates to control the release from gated MSN and mesoporous Janus nanoparticles. ${ }^{22,23}$

With the aim of advancing the preparation of more complex enzyme-containing nanodevices for smart delivery, we describe here an enzyme-controlled MSN nanomachine with a layer-by-layer supramolecular architecture. The core of this nanocarrier is based on MSN loaded with a selected cargo (see Scheme 1).

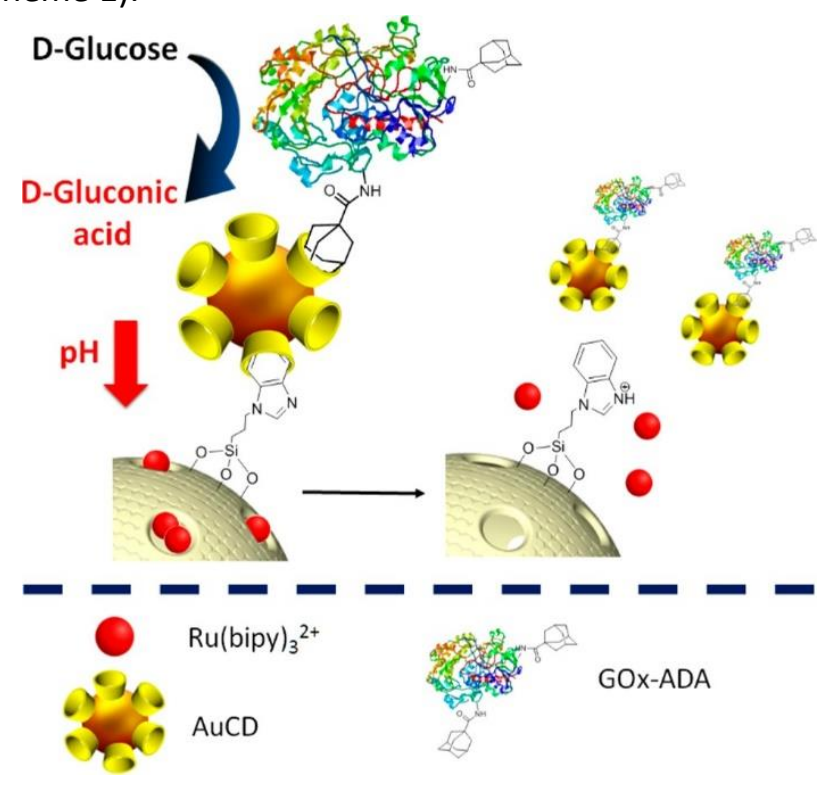

Scheme 1. Architecture and performance of the enzyme-controlled nanomachine upon addition of glucose, which is transformed to gluconic acid by Gox-ADA, disrupting the $\mathrm{pH}$-sensitive nanovalves and inducing cargo delivery.

This nanoparticle was then functionalized with benzimida- zole moieties able to form $\mathrm{pH}$ sensitive host-guest complexes with a first layer of $\beta$-cyclodextrin coated Au nanoparticles $(A u C D),{ }^{24,25}$ acting as gatelike nanovalve and double supramolecular bridge. Then, a second layer of adamantane-modified glucose oxidase $(G O x-A D A)^{16}$ was further immobilized by supramolecular association with the exposed $\beta$-cyclodextrin residues at the Au nanoparticle surface. This engineered nanomachine was able to release the cargo in an autonomous way upon addition of glucose, and was successfully evaluated as smart delivery system for an anticancer drug in in vitro and ex vivo experiments.

Scheme 2 represents the experimental steps involved in the assembly of the glucose-responsive nanomachine. MSN was first prepared by hydrolysis and condensation of tetraethyl orthosilicate in alkaline media using the surfactant cetyltrimethylammonium bromide as a porogenic agent. ${ }^{17}$ The starting mesoporous nanoparticles (solid SO) was then obtained after removal of the surfactant molecules by calcination in air at high temperature. In a second step, SO was loaded with tris(bipyridine)ruthenium(II) chloride $\left(\left[\mathrm{Ru}(\mathrm{bpy})_{3}\right] \mathrm{Cl}_{2}\right)$ to act as reporter dye, and the hydroxyl groups at the external nanoparticle's surface were reacted with 3-iodopropyltrimethoxysilane. To construct the $\mathrm{pH}$-sensitive gatelike scaffolding, we then grafted benzimidazole molecules to 3-iodopropyl moieties through a nucleophilic substitution reaction, generating a nanoparticle modified with 1-propyl-1-H-benzimidazole residues (solid S1). ${ }^{16}$ 
In parallel, per-6-thio-6-deoxy- $\beta$-cyclodextrin was synthesized as previously described ${ }^{25}$ to further prepare AuCD (ca. 3-5 nm) by reduction of $\mathrm{HAuCl} 4$ with $\mathrm{NaBH} 4$ in the presence of the cyclodextrin derivative. ${ }^{24,25}$ This nanoparticle was layered on the S1 surface by simple incubation in aqueous media with AuCD, yielding the solid S2.

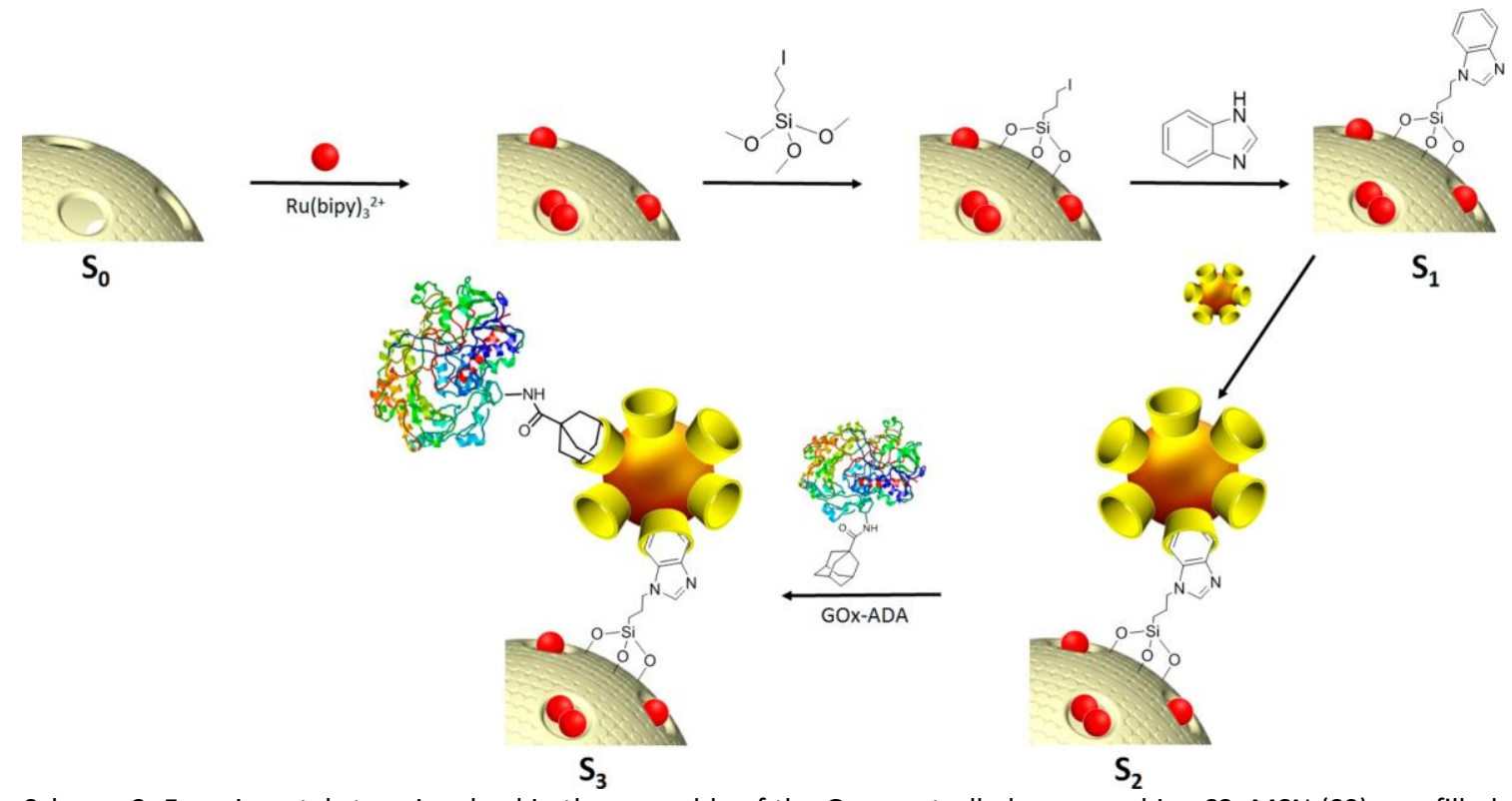

Scheme 2. Experimental steps involved in the assembly of the Gox-controlled nanomachine S3. MSN (S0) was filled with $\left[\mathrm{Ru}(\mathrm{bpy})_{3}\right] \mathrm{Cl}_{2}$ and further modified with 3-iodopropyltrimethoxysilane and benzimidazole to yield S1. Capping with AuCD leads to solid S2, which was then functionalized with GOx-ADA derivative via host-guest interactions to produce S3.

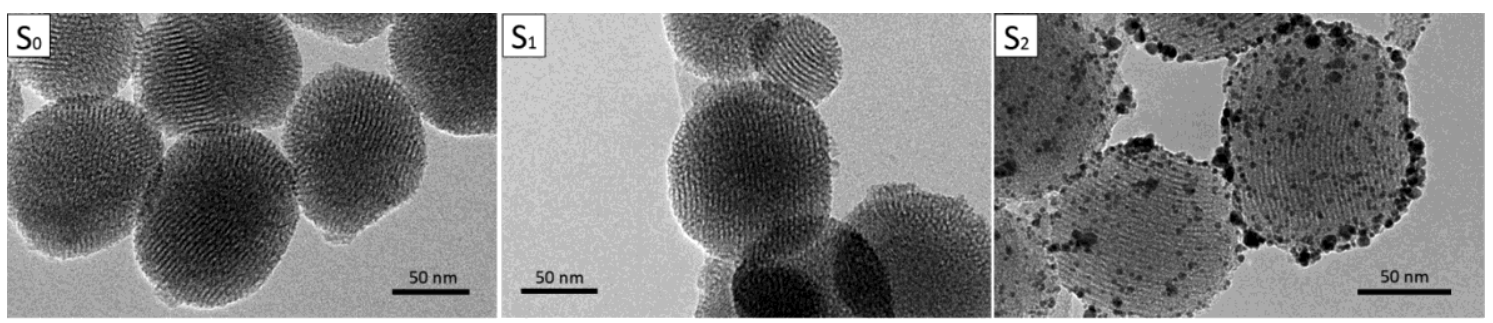

Figure 1. Representative TEM images of solids S0, S1, and S2.

These intermediate supports (S0, S1, and S2 nanoparticles) were characterized by different techniques. TEM analysis revealed a spherical shape with average diameter of $110 \pm 7 \mathrm{~nm}$ and the characteristic pore morphology of MCM-41 for all mesoporous silica nanoparticles (Figure 1). In addition, the presence of AuCD homogeneously attached to the mesoporous silica nanoparticle surface in solid S2 was clearly evidenced.

The X-ray diffraction analysis of all intermediate adducts are shown in Figure 2A. All solids showed a peak around $2.6^{\circ}$ corresponding to the (100) Bragg reflection of MCM-41 materials with $\mathrm{d}$-spacing values of $3.40 \mathrm{~nm} \cdot{ }^{17}$ This fact suggests a mesoporous order in these nanomaterials, which was not affected by the different modification and dye loading processes. On the other hand, the diffraction pattern of solid S2 at high angles revealed the cubic gold characteristic (111), (200), (220) and (311) diffraction peaks, ${ }^{26}$ confirming the presence of AuCD colloids in this nanodevice as previously observed by TEM. The presence of AuCD in S2 was also confirmed by the broad absorption band around $570 \mathrm{~nm}$ in the UV-vis spectrum (Figure S1). 

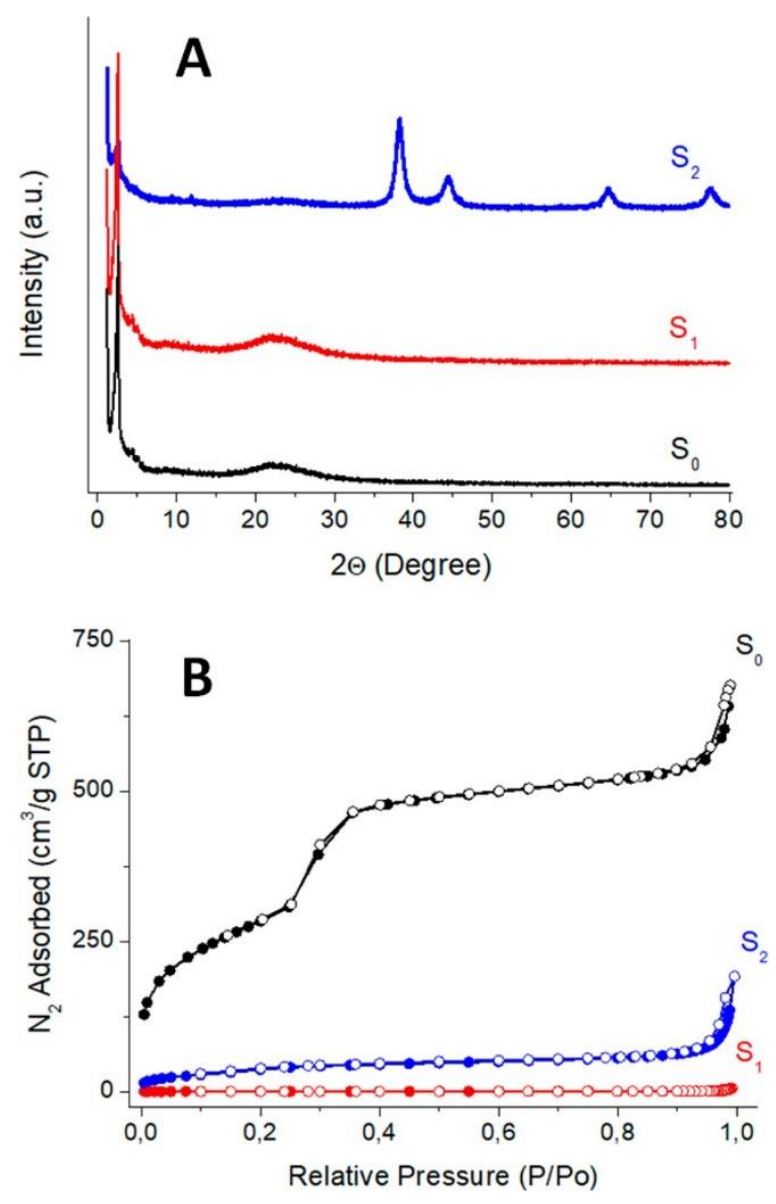

Figure 2. (A) Powder X-ray patterns and (B) $\mathrm{N}_{2}$ adsorption (closed)/desorption (open) isotherms for S0, S1, and S2 nanoparticles.

The N2 adsorption/desorption isotherms of all intermediate supports are shown Figure 2B. Solid SO showed the typical type IV isotherms of MCM-41 mesoporous nanoparticles, with a BET specific surface of $1053 \mathrm{~m}^{2} / \mathrm{g}$ an average pore size of ca. $2.2 \mathrm{~nm}$ (see Figure S2). On the contrary, solid S1 showed the characteristic $\mathrm{N}_{2}$ adsorption/desorption isotherms of meso- porous materials with filled pores, and accordingly, no appreciable porosity was observed. This pattern indicates high load of $\left[\mathrm{Ru}(\mathrm{bpy})_{3}\right] \mathrm{Cl}_{2}$ into the mesopores of the nanoparticles. The BET specific surface value for this filled nanomaterial was estimated as $19 \mathrm{~m}^{2} / \mathrm{g}$. Solid S2 showed similar behavior, but some $\mathrm{N}_{2}$ adsorption was observed at high relative pressure values, suggesting that some pores were partially emptied because of the release of some $\left[\mathrm{Ru}(\mathrm{bpy})_{3}\right] \mathrm{Cl}_{2}$ molecules during the capping process with AuCD. The BET specific surface of this capped solid was calculated as $143 \mathrm{~m}^{2} / \mathrm{g}$. FT-IR spectroscopy was also employed to characterize these nanomaterials. As can be observed in Figure S3, solid S0 showed the characteristics spectra of siliceous materials, ${ }^{22}$ with adsorption bands at $4570,573,807,951$, and $1085 \mathrm{~cm}^{-1}$ attributed to the $\mathrm{Si}-\mathrm{O}, \mathrm{Si}-\mathrm{O}-\mathrm{Si}, \mathrm{SiO} 4, \mathrm{Si}-\mathrm{OH}$, and $\mathrm{Si}-\mathrm{O}-\mathrm{Si}$ vibrations. The broad band centered at and 3432 $\mathrm{cm}^{-1}$ can be attributed to the $\mathrm{O}-\mathrm{H}$ bonding vibration of adsorbed water and $\mathrm{SiO}-\mathrm{H}$ groups. The spectrum of solid S1 showed the bands of $\left[\mathrm{Ru}(\mathrm{bpy})_{3}\right] \mathrm{Cl}_{2}$ at 1462,1447 , and $1421 \mathrm{~cm}^{-1,27}$ as well as the $\mathrm{C}-\mathrm{H}$ in-plane bending vibration at $1233 \mathrm{~cm}^{-1}$ and the $\mathrm{C}-\mathrm{H}$ out-of-plane bending vibration at 767 and $748 \mathrm{~cm}^{-1}$ corresponding to the benzimidazole residues attached to the mesoporous silica surface. ${ }^{28}$ The intensity of these bands was significantly reduced after incubation with AuCD because of the formation of supramolecular associations in solid S2. The presence of CD 
moieties in this solid was also confirmed by the band at $2934 \mathrm{~cm}^{-1}$, which could be ascribed to $\mathrm{C}-\mathrm{H}$ groups in the oligosaccharide.

The total content of $\left[\mathrm{Ru}(\mathrm{bpy})_{3}\right] \mathrm{Cl}_{2}$ in solid $\mathrm{S} 2$ was estimated as $15 \mathrm{mmol} \mathrm{g}^{-1} \mathrm{SiO}_{2}$ by total alkaline hydrolysis of the capped nanomaterial. Moreover, thermogravimetric analysis revealed a $7.9 \%$ $(w / w)$ of Au in calcined S2 (Figure S4).

To assemble the integrated enzyme-controlled nanomachine S3, we first covalently modified glucose oxidase with 1-adamantane carboxylic acid yielding the GOx-ADA derivative. This modified enzyme was then layered on S2 support through the formation of host-guest supramolecular complexes with the free $\beta$-cyclodextrin residues at the AuCD surface. The resulting S3 nanodevice with a layer-by-layer design contained about $6 \times 10-5 \mathrm{mg}$ GOx-ADA per gram of nanoparticle, representing $1.27 \mathrm{U} \mathrm{mg}-1 \mathrm{~S} 3$.

These nanoparticles were finally characterized by dynamic light scattering, and the results are shown in Figure $\mathrm{S} 5$ in Supporting Information. Functionalization with benzimidazol residues and loading with $\left[\mathrm{Ru}(\mathrm{bpy})_{3}\right] \mathrm{Cl}_{2}$ slightly increased the hydrodynamic diameter and reduced the zeta potential of solid S1 $(114.2 \mathrm{~nm},-41.0 \mathrm{mV})$, in comparison with the starting solid S0 (102.4 nm, $-43.5 \mathrm{mV}$ ). Capping with AuCD lead to higher increase in the hydrodynamic diameter ( $179.7 \mathrm{~nm}$ ) and a noticeable reduction in the zeta potential value $(-21.7 \mathrm{mV})$ for solid $\mathrm{S} 2$. For the final solid S3, supramolecular immobilization of GOx-ADA caused a significant increase in the surface charge and hydrodynamic diameter, reaching values of $-35.3 \mathrm{mV}$ and $214.7 \mathrm{~nm}$, respectively.
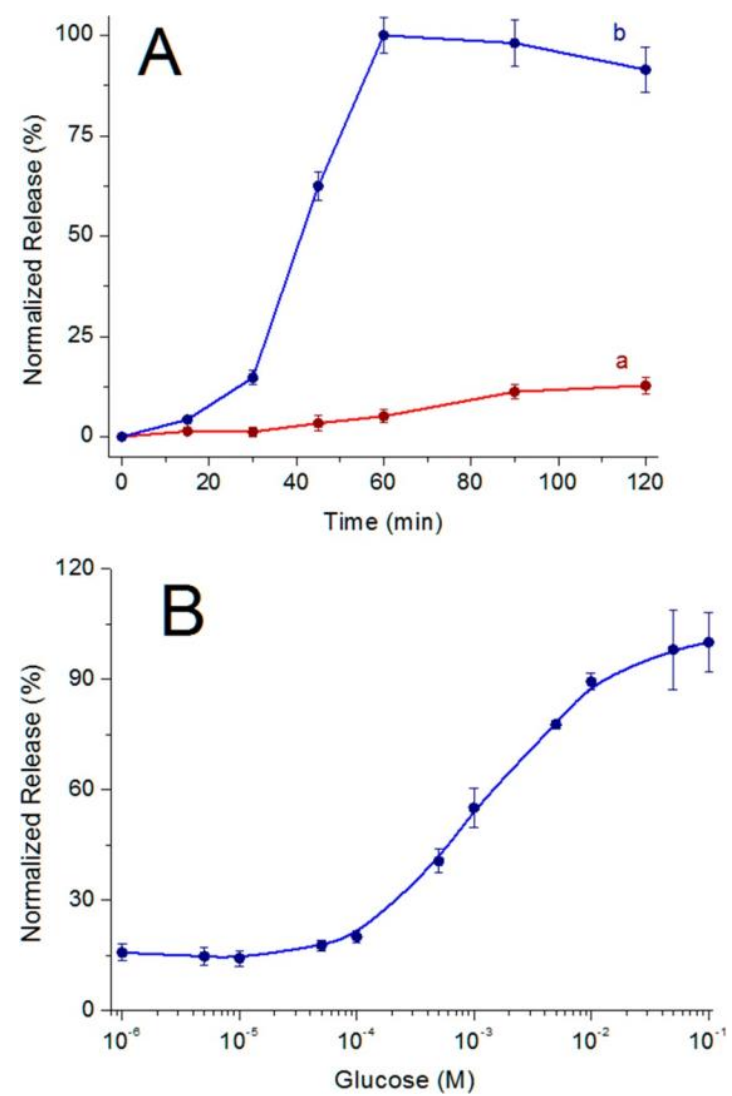

Figure 3. (A) Kinetics of $\left[\mathrm{Ru}(\mathrm{bpy})_{3}\right] \mathrm{Cl}_{2}$ dye release from $\mathrm{S} 3$ in $20 \mathrm{mM} \mathrm{Na}_{2} \mathrm{SO}_{4}, \mathrm{pH} 7.5$ (a) without and (b) with addition of glucose at a $50 \mathrm{mM}$ final concentration. (B) Effect of glucose concentration on the normalized release of $\left[\mathrm{Ru}(\mathrm{bpy})_{3}\right] \mathrm{Cl}_{2}$ from $\mathrm{S} 3$ after 60 min of incubation.

S3 nanomachine was tested for the on-command controlled delivery of the $\left[\mathrm{Ru}(\mathrm{bpy})_{3}\right] \mathrm{Cl}_{2}$ dye. In a typical release assay, $6 \mathrm{mg}$ of S3 were suspended in $3 \mathrm{~mL}$ of $20 \mathrm{mM} \mathrm{Na} 2 \mathrm{SO} 4$ solution at pH 7.5, 
and were shaken over time at $25^{\circ} \mathrm{C}$. Aliquots were periodically taken, centrifuged to remove the nanomaterial, and the absorbance $454 \mathrm{~nm}$ was then measured. As trigger for $\left[\mathrm{Ru}(\mathrm{bpy})_{3}\right] \mathrm{Cl}_{2}$ release, $50 \mathrm{mM}$ D-glucose was employed. As control, a similar assay was executed in parallel, but without addition of D-glucose.

As Figure $3 \mathrm{~A}$ illustrates, a negligible release of $\left[\mathrm{Ru}(\mathrm{bpy})_{3}\right] \mathrm{Cl}_{2}$ was observed in the absence of glucose, suggesting S3 nanomachine is still tightly capped. On the contrary, the addition of glucose resulted in the opening of pores in S3 producing a subsequent cargo delivery. This behavior can be explained by the enzymatic transformation of glucose to gluconic acid, with a consequent drop in $\mathrm{pH}$ at the microenvironment of the nanomachine. This acid media causes protonation of the benzimidazole moieties at the nanomachine surface, then disrupting the supramolecular complexes with $\mathrm{AuCD}$ and inducing $\left[\mathrm{Ru}(\mathrm{bpy})_{3}\right] \mathrm{Cl}_{2}$ release.

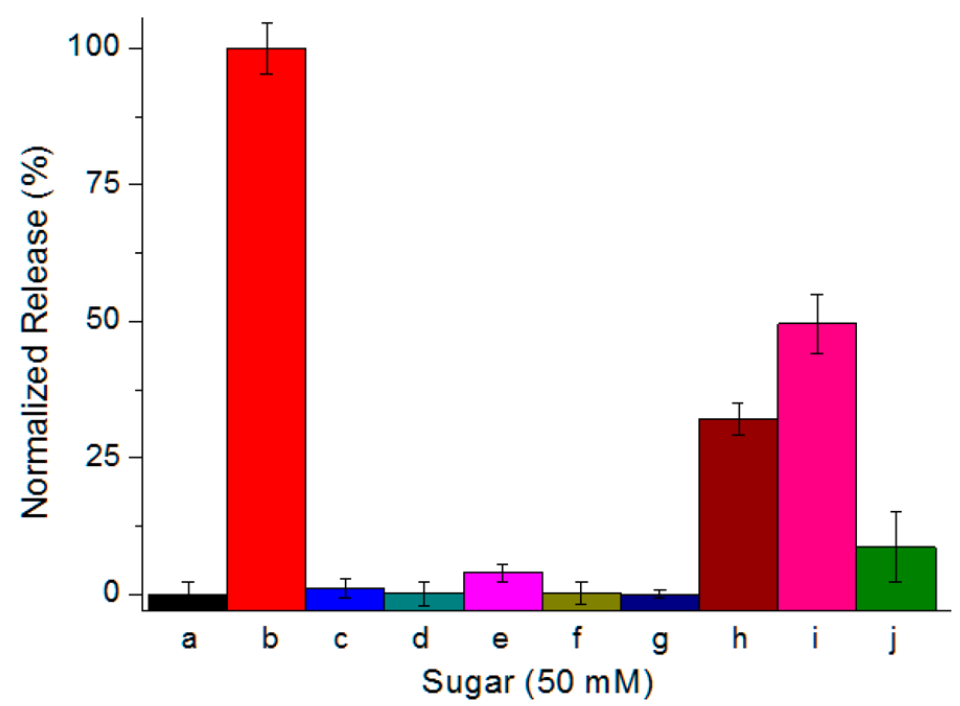

Figure 4. Effect of different sugars (a: blank; b: glucose; c: sucrose; d: fructose; e: lactose; f: galactose; g: ribose; h: mannose; i: 2-deoxy-D- glucose; j: lactulose) at $50 \mathrm{mM}$ concentration, on the normalized release of $\left[\mathrm{Ru}(\mathrm{bpy})_{3}\right] \mathrm{Cl}_{2}$ from S3 after 60 min incubation.

To confirm this opening mechanism, we measured $\mathrm{pH}$ in both control and releasing systems. $\mathrm{pH}$ of the incubating media remained unchanged in the control experiment, but changed from 7.5 to ca. 5.2 after incubation with glucose. In addition, suspensions of $S 3$ were heated at $100^{\circ} \mathrm{C}$ for 10 min to inactivate the immobilized enzyme, and were further incubated with glucose. In this case, no appreciable dye release was observed from this thermal inactivated sample after $24 \mathrm{~h}$ of incubation, confirming that the opening mechanism was mediated by the glucose oxidase catalyzed reaction in the presence of glucose. This mechanism may be of interest for the design of glucose-triggered cargo delivery nanodevices able to detect fluctuations in blood glucose concentrations and release a cargo though a self-regulated process, which is still a challenge. ${ }^{16,20}$

Figure 3B reports the dye release response of S3 nanodevice after 60 min incubation at pH 7.5 with different concentrations of D-glucose. Null or negligible release of the encapsulated dye molecules was observed at low D-glucose concentrations, but S3 exhibited a linear release response vs the logarithm of D- glucose concentration between $100 \mu \mathrm{M}$ and $10 \mathrm{mM}$.

To evaluate the specificity of this nanomachine, solid S3 was tested toward different sugars, and compared with the release response obtained toward glucose. As can been observed in Figure 4 , the $\mathrm{S} 3$ nanodevice released a high amount of $\mathrm{Ru}\left(\right.$ bipy ${ }_{3} \mathrm{Cl}_{2}$ dye after incubation with $\mathrm{D}$-glucose, 
and a low degree of dye delivery was observed in the presence of other sugars such as sucrose, fructose, lactose, galactose, ribose and lactulose. Only mannose and 2-deoxy-D-glucose caused a relative high release when used as triggers. This behavior can be explained by the intrinsic selectivity of glucose oxidase, which can also slightly recognize these two monosaccharides as potential substrates. ${ }^{29}$

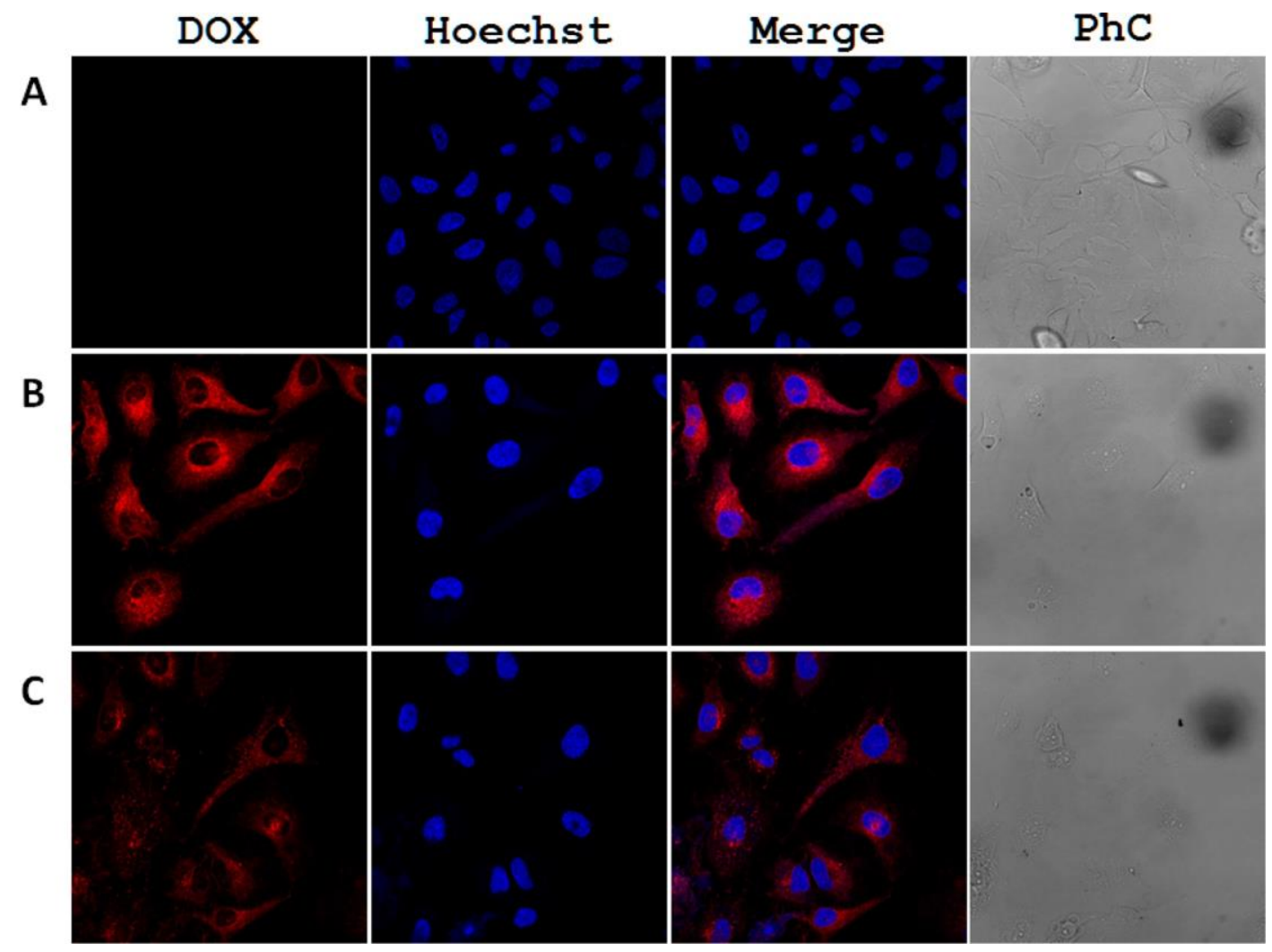

Figure 5. Confocal microscopy images of HeLa cells (A) untreated and incubated with $50 \mu \mathrm{g} / \mathrm{mL}$ of S4 in the (B) presence and $(\mathrm{C})$ absence of glucose. Images were acquired after $24 \mathrm{~h}$ of incubation from phase contrast (PhC), Doxo (DOX), Hoescht, and combined (Merge).

It should be highlighted that solid S3 showed high storage stability, retaining the mesoporous morphology (Figure S6) and more than 92 of the initial enzymatic activity after 3 months of storage at $4{ }^{\circ} \mathrm{C}$ in $20 \mathrm{mM} \mathrm{Na}_{2} \mathrm{SO}_{4}, \mathrm{pH} 7.5$.

To evaluate the possibilities of this enzyme-controlled nanomachine for drug delivery, we prepared a new $\mathrm{S} 4$ nanodevice by loading the nanodevice with the cytotoxic doxorubicin (Doxo) in Doxo-saturated aqueous solution, instead of $\mathrm{Ru}\left(\right.$ bipy ${ }_{3} \mathrm{Cl}_{2}$ dye. The amount of Doxo loaded on the nanomachine was estimated spectrophotometrically as $0.5 \mu \mathrm{mol}$ per gram of nanoparticles.

It was further determined that the $\mathrm{S} 4$ nanomachine showed a similar release pattern for Doxo than those obtained for $\mathrm{S} 3$ filled with $\mathrm{Ru}\left(\right.$ bipy ${ }_{3} \mathrm{Cl}_{2}$ dye upon addition of glucose (Figure S7). Accordingly, this nanomachine was evaluated for on-command release of Doxo to HeLa cancer cells in ex vivo experiments.

S4 was then evaluated toward HeLa cells under the premise that the nanocarrier can be internalized by the cells and the supramolecular gate-like ensemble remains closed until glucose is added. We also hypothesized that the immobilized enzyme remains active into the cell, and is able to induce a $\mathrm{pH}$ reduction at the microenvironment of the nanomachine after exposure to glucose, allowing intracellular release of Doxo and causing cell death. 
In a typical assay, HeLa cells were suspended in PBS supplemented with $10 \%$ fetal bovine serum and further incubated with a suspension of $50 \mu \mathrm{g} / \mathrm{mL}$ of S4 during $30 \mathrm{~min}$. HeLa cells were then washed with PBS to eliminate uninternalized nanoparticles and then incubated either in the absence or in the presence of D-glucose. The release of Doxo from solid S4 was study by confocal microscopy, by tracking drug-associated fluorescence signal. Furthermore, Hoechst 33342 was employed to stain the nuclei in HeLa cancer cells. Figure 5 shows representative confocal images of phase

contrast, Doxo (red), Hoescht (blue, for HeLa nuclei staining) and combined Doxo+Hoescht (red and blue) for untreated HeLa cells, as well as for cells initially treated with S4 and further incubated in the presence and the absence of D-glucose. Internalization of the nanodevice did not produce a noticeable drug release in the incubation media without D- glucose, suggesting that not unspecific Doxo delivery occurred in a large extent. Accordingly, weak and concentrated red fluorescence signals were observed, due to quenching of Doxo fluorescence by the nanoparticles. On the contrary, a clear and disperse red fluorescence was observed for those cells incubated with D-glucose, indicating that this monosaccharide triggered the release of the encapsulated Doxo molecules from the S4 nanomachine.

Similar results were achieved by using fluorescence microscopy (Figure S8). It was also demonstrated that the nanoparticles and the release of Doxo were homogeneously distributed into the cells, as observed by high resolution confocal images (Figure S9).

Cell viability assays were carried out on HeLa cells treated with S4 nanomachine during $24 \mathrm{~h}$. In addition, WST-1 assay was employed as quantification method. As can be observed in Figure 6, solid S4 was not toxic for HeLa cancer cells, not causing noticeable cell death after internalization in the absence of D-glucose even at a concentration as high as $100 \mu \mathrm{g} / \mathrm{mL}$. On the contrary, apoptotic cell death was observed for HeLa cancer cells treated with S4 in the presence of Dglucose.

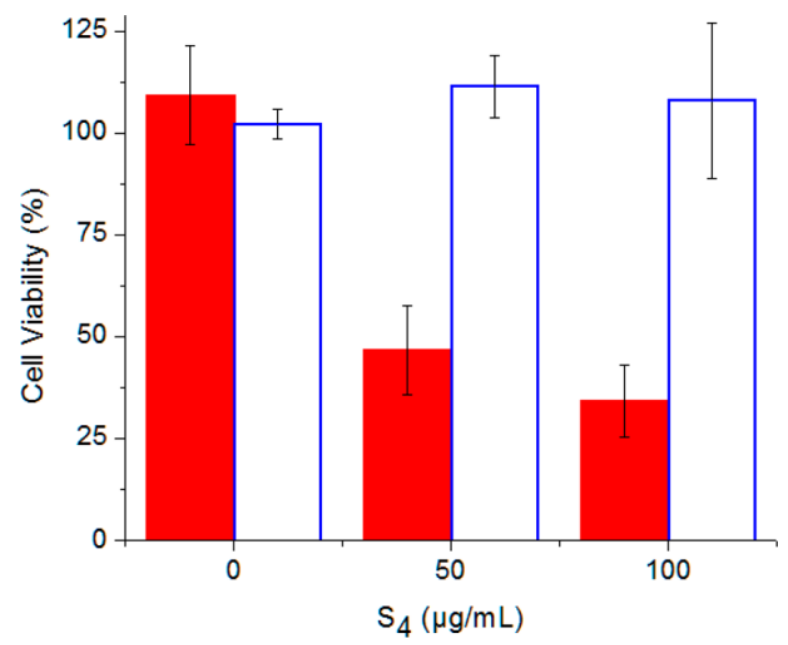

Figure 6. Cell viability assay for HeLa cancer cells incubated for $24 \mathrm{~h}$ with $50 \mu \mathrm{g} / \mathrm{mL}$ and $100 \mu \mathrm{g} / \mathrm{mL} \mathrm{S4}$ in the presence (filled) and absence (open) of glucose, using the WST-1 assay.

In this sense, an average of 53 and $64 \%$ of cells were dead after $24 \mathrm{~h}$ of incubation with S4 at 50 and $100 \mu \mathrm{g} / \mathrm{mL}$, respectively. As final remark, it should be highlighted that the release mechanism for this nanocarrier is driven by local changes in $\mathrm{pH}$, here fuelled by the enzymatic transformation of glucose. 
Accordingly, it would be expected that changes in intracellular or blood $\mathrm{pH}$, as well as the presence of autogenous glucose should impact on the release of the drug. In our experimental models, not specificity Doxo release was observed, suggesting that the intracellular $\mathrm{pH}$ or autogenous glucose concentration in HeLa cells not caused uncapping of the host-guest supramolecular nanovalves in solid S4. However, for practical application of this nanomaterial as autonomous drug delivery system, further in vivo experiments should be performed to evaluated the potential interfering effect of $\mathrm{pH}$, glucose and blood components.

In summary, here we reported the layer-by-layer supra- molecular assembly of a pH-sensitive and enzyme-controlled nanomachine for on-command release. This nanomachine, based on a benzimidazole-modified MSN capped with AuCD and powered by a glucose oxidase derivative, was able to deliver the encapsulated cargo in the presence of D-glucose. The nanomachine was also successfully used to release the anticancer drug Doxo in HeLa cancer cells. We can envision that these results can open new possibilities for the assembly of a large variety of enzymecontrolled nanomachines for smart and controlled delivery by rational selection of capping nanoparticles, opening mechanisms, and control enzymes.

\section{METHODS}

Preparation S0. To prepare the starting MSN (SO), we placed $1.0 \mathrm{~g}$ of cetyltrimethylammonium bromide in a $1.0 \mathrm{~L}$ three-neck round- bottom flask, and $480 \mathrm{~mL}$ of double-distilled water were added. ${ }^{17}$ The surfactant was dissolved under sonication, and then $3.5 \mathrm{~mL}$ of $2.0 \mathrm{~mol} / \mathrm{L} \mathrm{NaOH}$ solution were added. The temperature of the mixture was adjusted to $80{ }^{\circ} \mathrm{C}$ and $5.0 \mathrm{~mL}$ tetraethoxysilane were added dropwise to the solution within 5 min under vigorous magnetic stirring. The mixture was allowed to react for $2 \mathrm{~h}$. The resulting white solid was filtered, washed with water and methanol, and then dried in desiccator. To remove the surfactant template, the solid was finally calcined at $550^{\circ} \mathrm{C}$ for $5 \mathrm{~h}$.

Preparation of S1. To prepare the dye-loaded benzimidazole- coated MSN (S1), we suspended $500 \mathrm{mg}$ of $\mathrm{SO}$ and $300 \mathrm{mg}(39.6 \mu \mathrm{mol})$ of Ru(bipy) ${ }_{3} \mathrm{Cl}_{2} \cdot 6 \mathrm{H}_{2} \mathrm{O}$ in $25 \mathrm{~mL}$ of anhydrous acetonitrile and heated it at $120^{\circ} \mathrm{C}$ in a Dean-Stark apparatus under Ar atmosphere to remove the adsorbed water. ${ }^{16}$ The mixture was stirred for $24 \mathrm{~h}$ at room temperature to load the dye into the MSN face pores. Afterward, an excess of (3-iodopropyl)trimethoxysilane (196 $\mu \mathrm{L}, 1 \mathrm{mmol}$ ) was added and the suspension was stirred for $5.5 \mathrm{~h}$. The resulting solid was filtered off, washed two times with $10 \mathrm{~mL}$ toluene. The solid was further dispersed in $40 \mathrm{~mL}$ of a saturated solution of benzimidazole in toluene containing triethylamine (benzimidazol and triethylamine in a 1:3 proportion) at 80 ${ }^{\circ} \mathrm{C}$. The suspension was refluxed and stirred during $72 \mathrm{~h}$. The final orange solid (S1) was filtered off, washed several times with acetonitrile, and dried at $70^{\circ} \mathrm{C}$ overnight.

Preparation of S2. AuCD were first prepared as previously reported, ${ }^{24,25}$ by using perthiolated $\beta$ cyclodextrin as capping molecules and a $\beta$-cyclodextrin: $\mathrm{HAuCl} 4$ molar ratio of $1: 5$. Briefly, $50 \mathrm{mg}$ of $\mathrm{HAuCl}_{4}$ were dissolved in $20 \mathrm{~mL}$ of DMSO, and the resulting solution was quickly mixed with another $20 \mathrm{~mL}$ of DMSO containing $76 \mathrm{mg}$ of $\mathrm{NaBH}_{4}$ and $33 \mathrm{mg}$ of perthiolated $\beta$-cyclodextrin. The mixture was kept under continuous stirring during $24 \mathrm{~h}$, and then $40 \mathrm{~mL}$ of $\mathrm{CH}_{3} \mathrm{CN}$ was added to precipitate the nanoparticles. The solid was collected by centrifugation, and sequentially washed with $60 \mathrm{~mL}$ of $\mathrm{CH}_{3} \mathrm{CN}$ : DMSO $(1: 1 \mathrm{v} / \mathrm{v})$ and $60 \mathrm{~mL}$ pf EtOH. The AuCD nanoparticles were finally isolated by centrifugation and dried under vacuum until use. 
To assemble the AuCD-capped nanodevice, we dispersed $30 \mathrm{mg}$ of solid S1 in $5 \mathrm{~mL}$ of $0.1 \mathrm{M}$

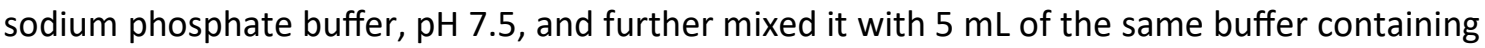
$75 \mathrm{mg}$ of AuCD and $20 \mathrm{mg}$ of $\mathrm{Ru}(\text { bipy })_{3} \mathrm{Cl}_{2} \cdot 6 \mathrm{H}_{2} \mathrm{O}$. The mixture was stirred overnight at room temperature, then centrifuged and the solid was washed several times with $0.1 \mathrm{M}$ sodium phosphate buffer, $\mathrm{pH} 7.5$, and dried in a desiccator.

Preparation of S3. GOx-ADA (specific activity: $0.93 \mathrm{U} / \mathrm{mg}$ ) was first synthesized as previously described. ${ }^{16}$ Briefly, $2.5 \mathrm{mg}$ of 1 - adamantylamine $(0.016 \mathrm{mmol})$ and $3 \mathrm{mg}$ of 1-ethyl-3-(3dimethyla- mino-propyl)carbodiimide hydrochloride $(0.016 \mathrm{mmol})$ were dispersed in $3 \mathrm{~mL}$ of 0.1 $\mathrm{M}$ sodium phosphate buffer, $\mathrm{pH}$ 6.0. To this solution was added $1.6 \mathrm{mg}$ of glucose oxidase (from A. niger, Type VII, Sigma-Aldrich) dissolved in $0.3 \mathrm{~mL}$ of the same buffer. The reaction mixture was stirred for $2 \mathrm{~h}$ at room temperature and further $20 \mathrm{~h}$ at $4{ }^{\circ} \mathrm{C}$. The solution was then dialyzed vs $0.1 \mathrm{M}$ sodium phosphate buffer, $\mathrm{pH} 7.0$, and concentrated by $30 \mathrm{~K}$ Amicon Ultra-05 centrifugal filter devices (EMD Millipore Corporation).

To prepare the enzyme-functionalized nanomachine, we dispersed $30 \mathrm{mg}$ of solid $\mathrm{S} 2$ in $4 \mathrm{~mL}$ of $0.1 \mathrm{M}$ sodium phosphate buffer, $\mathrm{pH} 7.5$, at $4{ }^{\circ} \mathrm{C}$, and then $156 \mu \mathrm{L}$ of a $60 \mathrm{mg} / \mathrm{mL} \mathrm{GOx}$-ADA solution were added. The mixture was stirred at $4{ }^{\circ} \mathrm{C}$ overnight, further centrifuged, and the resulting solid was washed twice with cold buffer. Solid S3 was then suspended in $10 \mathrm{mM}$ sodium phosphate buffer, $\mathrm{pH} 7.5$, at a $30 \mathrm{mg} / \mathrm{mL}$ final concentration and kept at $4{ }^{\circ} \mathrm{C}$ until use.

Release Assays. A $2.0 \mathrm{mg} / \mathrm{mL}$ suspension of $\mathrm{S} 3$ in $20 \mathrm{mM} \mathrm{Na}_{2} \mathrm{SO}_{4}, \mathrm{pH} 7.5$, was freshly prepared. For each batch experiment, aliquots of $3 \mathrm{~mL}$ were employed. To monitor the ruthenium complex release, we removed $0.3 \mathrm{~mL}$ of the suspension at scheduled times, then centrifuged, and the delivered cargo was registered via the $\mathrm{Ru}(\text { bipy })_{3} \mathrm{Cl}_{2}$. absorbance at $453 \mathrm{~nm}$. To trigger the release mechanism, we employed glucose at a $50 \mathrm{mM}$ final concentration as INPUT signal.

Cell Culture Conditions. HeLa human cells were grown and maintained as previously described. ${ }^{6}$

WST-1 Cell Viability Assay. This assay was performed as previously described by using solid S4 in DMSO at final concentrations of $50 \mu \mathrm{g} / \mathrm{mL}$ and $100 \mathrm{mg} / \mathrm{mL}^{6}$

Live Confocal Microscopy. Live confocal microscopy experiments were performed as described, ${ }^{6}$ using a suspension of solid S4 at a final concentration of $50 \mu \mathrm{g} / \mathrm{mL}$.

\section{ACKNOWLEDGMENTS}

Financial support from the Spanish Ministry of Economy and Competitiveness (projects CTQ2014-58989-P, CTQ2015- 71936-REDT, CTQ2017-87954-P, and MAT2015-64139-C4-1-R) and generalitat Valenciana (project PROMETEO/2018/024) is gratefully acknowledged. 


\section{REFERENCES}

(1) Zhang, P.; Jiang, J.; Yuan, R.; Zhuo, Y.; Chai, Y. Highly ordered and field-free 3D DNA nanostructure: the next generation of DNA nanomachine for rapid single-step sensing. J. Am. Chem. Soc. 2018, 140, 9361-9364.

(2) Ranallo, S.; Prev́ost-Tremblay, C.; Idili, A.; Valleé-Belísle, A.; Ricci, F. Antibody-powered nucleic acid release using a DNA-based nanomachine. Nat. Commun. 2017, 8, 15150.

(3) Diez, P.; Esteban-Fernandez de Avila, B.; Ramirez-Herrera, D. E.; Villalonga, R.; Wang, J. Biomedical nanomotors: efficient glucose- mediated insulin release. Nanoscale 2017, 9, 14307-14311.

(4) Zhang, P.; Jiang, J.; Yuan, R.; Zhuo, Y.; Chai, Y. Highly orderedband field-free 3D DNA nanostructure: the next generation of DNA nanomachine for rapid single-step sensing. J. Am. Chem. Soc. 2018, 140, 9361-9364.

(5) Ruehle, B.; Clemens, D. L.; Lee, B. Y.; Horwitz, M. A.; Zink, J. I. A pathogen-specific cargo delivery platform based on mesoporous silica nanoparticles. J. Am. Chem. Soc. 2017, 139, 6663-6668.

(6) Díez, P.; Sa'nchez, A.; Torre, C. D. L.; Gamella, M.; Martínez- Ruíz, P.; Aznar, E.; MartínezMañez, R.; Pingarro'n, J. M.; Villalonga, R. Neoglycoenzyme-gated mesoporous silica nanoparticles: toward the design of nanodevices for pulsatile programmed sequential delivery. ACS Appl. Mater. Interfaces 2016, 8, 7657-7665.

(7) Ummat, A.; Dubey, A.; Mavroidis, C. Bio-nanorobotics: a field inspired by Nature. In Biomimetics: Biologically Inspired Technologies; Bar-Cohen, Y., Ed.; CRC Press: Boca Raton, FL, 2005; pp 201-228.

(8) Yao, X.; Niu, X.; Ma, K.; Huang, P.; Grothe, J.; Kaskel, S.; Zhu, Y. Graphene quantum dotscapped magnetic mesoporous silica nanoparticles as a multifunctional platform for controlled drug delivery, magnetic hyperthermia, and photothermal therapy. Small 2017, 13, 1602225.

(9) Palanikumar, L.; Choi, E. S.; Cheon, J. Y.; Joo, S. H.; Ryu, J. H. Noncovalent polymergatekeeper in mesoporous silica nanoparticles as a targeted drug delivery platform. Adv. Funct. Mater. 2015, 25, 957-965.

(10) Cheng, W.; Nie, J.; Xu, L.; Liang, C.; Peng, Y.; Liu, G.; Wang, T.; Mei, L.; Huang, L.; Zeng, $\mathrm{X}$. $\mathrm{pH}$-Sensitive delivery vehicle based on folic acid-conjugated polydopamine-modified mesoporous silica nanoparticles for targeted cancer therapy. ACS Appl. Mater. Interfaces 2017, 9, 18462-18473.

(11)Aznar, E.; Oroval, M.; Pascual, L.; Murguía, J. R.; Martinez- Manez, R.; Sancenon, F. Gated materials for on-command release of guest molecules. Chem. Rev. 2016, 116, 561-718.

(12) Song, N.; Yang, Y. W. Molecular and supramolecular switches on mesoporous silica nanoparticles. Chem. Soc. Rev. 2015, 44, 3474- 3504.

(13) Van Rijt, S. H.; Bölükbas, D. A.; Argyo, C.; Datz, S.; Lindner, M.; Eickelberg, O.; Königshoff, M.; Bein, T.; Meiners, S. Protease- mediated release of chemotherapeutics from mesoporous silica nanoparticles to ex vivo human and mouse lung tumors. ACS Nano 2015, 9, 2377-2389.

(14)Lee, B. Y.; Li, Z.; Clemens, D. L.; Dillon, B. J.; Hwang, A. A.; Zink, J. I.; Horwitz, M. A. Redoxtriggered release of moxifloxacin from mesoporous silica nanoparticles functionalized with disulfide snap-tops enhances efficacy against pneumonic tularemia in mice. Small 2016, 12, 3690-3702. 
(15)Anirudhan, T. S.; Nair, A. S. Temperature and ultrasound sensitive gatekeepers for the controlled release of chemotherapeutic drugs from mesoporous silica nanoparticles. J. Mater. Chem. B 2018, 6, 428-439.

(16)Aznar, E.; Villalonga, R.; Gimeńez, C.; Sancenoń, F.; Marcos, M. D.; Martínez-Mañez, R.; Díez, P.; Pingarroń, J. M.; Amoroś, P. Glucose-triggered release using enzyme-gated mesoporous silica nanoparticles. Chem. Commun. 2013, 49, 6391-6393.

(17)Villalonga, R.; Díez, P.; Sańchez, A.; Aznar, E.; Martínez- Mañez, R.; Pingarroń, J. M. Enzyme-controlled sensing-actuating nanomachine based on Janus Au-mesoporous silica nanoparticles. Chem. - Eur. J. 2013, 19, 7889-7894.

(18)Llopis-Lorente, A.; De Luis, B.; García-Fernańdez, A.; Díez, P.; Sańchez, A.; Marcos, M. D.; Villalonga, R.; Martínez-Mañez, R.; Sancenón, F. Au-Mesoporous silica nanoparticles gated with disulfide-linked oligo (ethylene glycol) chains for tunable cargo delivery mediated by an integrated enzymatic control unit. J. Mater. Chem. B 2017, 5, 6734-6739.

(19)Llopis-Lorente, A.; Díez, P.; De la Torre, C.; Sańchez, A.; Sancenoń, F.; Aznar, E.; Marcos, M. D.; Martínez-Ruíz, P.; Martínez- Mañez, R.; Villalonga, R. Enzyme-controlled nanodevice for acetylcholine-triggered cargo delivery based on Janus Au-mesopo-rous silica nanoparticles. Chem. - Eur. J. 2017, 23, 4276-4281.

(20)Oroval, M.; Díez, P.; Aznar, E.; Coll, C.; Marcos, M. D.; Sancenoń, F.; Villalonga, R.; Martínez-Mañez, R. Self-regulated glucose-sensitive neoglycoenzyme-capped mesoporous silica nano- particles for insulin delivery. Chem. - Eur. J. 2017, 23, 1353-1360.

(21)Llopis-Lorente, A.; Díez, P.; Sańchez, A.; Marcos, M. D.; Sancenoń, F.; Martínez-Ruiz, P.; Villalonga, R.; Martínez-Mañez, R. Interactive models of communication at the nanoscale using nanoparticles that talk to one another. Nat. Commun. 2017, 8, 15511.

(22)Díez, P.; Sańchez, A.; Gamella, M.; Martínez-Ruíz, P.; Aznar, E.; De La Torre, C.; Murguía, J. R.; Martínez-Mañez, R.; Villalonga, R.; Pingarro'n, J. M. Toward the design of smart delivery systems controlled by integrated enzyme-based biocomputing ensembles. J. Am. Chem. Soc. 2014, 136, 9116-9123.

(23)Llopis-Lorente, A.; de Luis, B.; Garci'a-Ferna'ndez, A.; Jimenez-Falcao, S.; Orza'ez, M.; Sanceno'n, F.; Villalonga, R.; Marti'nez-Ma'ñez, R. Hybrid mesoporous nanocarriers act by processing logic tasks: Toward the design of nanobots capable of reading information from the environment. ACS Appl. Mater. Interfaces 2018, 10, 26494-26500.

(24)Villalonga, R.; Cao, R.; Fragoso, A.; Damiao, A. E.; Ortiz, P. D.; Caballero, J. Supramolecular assembly of $\beta$-cyclodextrin-modified gold nanoparticles and $\mathrm{Cu}, \mathrm{Zn}$ superoxide dismutase on catalase. J. Mol. Catal. B: Enzym. 2005, 35, 79-85.

(25)Liu, J.; Ong, W.; Romań, E.; Lynn, M. J.; Kaifer, A. E. Cyclodextrin-modified gold nanospheres. Langmuir 2000, 16, 3000-3002.

(26)Leff, D. V.; Brandt, L.; Heath, J. R. Synthesis and characterization of hydrophobic, organically-soluble gold nanocrystals functionalized with primary amines. Langmuir 1996, 12, 4723-4730.

(27)Omberg, K. M.; Schoonover, J. R.; Treadway, J. A.; Leasure, R. M.; Dyer, R. B.; Meyer, T. J. Mid-infrared spectrum of [Ru(bpy)3]2+. J. Am. Chem. Soc. 1997, 119, 7013-7018.

(28)Mohan, S.; Sundaraganesan, N.; Mink, J. FTIR and Raman studies on benzimidazole. Spectrochim. Acta, Part A 1991, 47, 1111- 1115.

(29)Keilin, D.; Hartree, E. F. Properties of glucose oxidase (notatin). Biochem. J. 1948, 42, 221-229. 